\title{
Abstracts of Papers Presented at the Annual Meeting
}

\author{
SESSION 1A: WATER, MINERALS, AND LABOR: MANAGING RESOURCES IN THE \\ WESTERN ECONOMY
}

\section{Wages in California During the Gold Rush}

The Califormia Gold Rush was an unexpected shock of tremendous size that prompted the costly reallocation of labor to a frontier region. Using newly collected archival data, this paper presents estimates of nominal and real wages in Gold Rush California. Consistent with a simple dynamic model of labor market adjustment, real wages rose sharply during the early years of the Rush (1848 to 1852), declined abruptly following massive inmigration, and then remained constant for the remainder of the $1850 \mathrm{~s}$. However, although the Rush itself was a transitory event, it left California wages permanently higher. Estimates based on census data suggest that the supply of labor into Gold Rush California was about half as elastic as the supply of labor in Alaska during the pipeline era.

ROBERT A. MARGO, Harvard University

Efficiency in Western Water Law: The Development of the California Doctrine, 1850-1911

The development of nineteenth-century water law had major consequences for water use throughout the western United States. Despite its importance, the origins of western water law and its efficiency implications remain unclear. This paper investigates an important feature of western water law: the existence, in a number of western states, of a hybrid system of water rights which simultaneously recognizes both water rights based on first possession (appropriative rights) and water rights based on common-pool sharing arrangements (riparian rights). Perhaps the key issue from the viewpoint of efficiency concerns the ability of this system to accommodate displacement of older claims by newer, more valuable, ones. A principal finding is that the Califomia courts promoted efficiency-enhancing reallocations through its rulings on transferability and reasonable use. This theoretical finding is corroborated by an econometric analysis of a set of California Supreme Court rulings on reasonaable riparian use in which the incidence of reasonableness requirements is positively correlated with the level of local transactions costs.

\section{Mark Kanazawa, Carleton College}

\section{Transactions Costs and the Value of Mining Claims, 1872-1920}

Economists and legal scholars have shown how and why legal institutions for allocating western mineral rights developed in response to the demands of mining interests for secure claim rights during the great western metal rushes of the mid-nineteenth century. The resultant federal law the Mining Law of 1872-also provides for the privatization of federal lands, though title is not necessary to mine. In this paper I model the decision to patent by comparing the relative values of untitled and titled mining claims. The central implication, which has been overlooked by both economists and legal scholars, is that mining interest patent claims in cases where the transaction costs of maintaining and enforcing claim rights to untitled claims exceed the costs of acquiring title. The model is supported with evidence from a cross-section of 12 western states and territories for the period 1881 to 1920 . The results suggest that private contracting efforts and common-law 
changes allowed an evolving mining industry to adapt to the parameters of a law written by and for a previous generation of miners.

DAVID GERARD, University of Illinois

\section{SESSION 1B: THE GROUND UP: ECONOMICS ISSUES IN PEASANT AGRICULTURE}

\section{The Shamrock and the Potato: The Agricultural System of Pre-Famine Ireland}

This paper seeks to explain the high crop yields observed in late eighteenth- and early nineteenth-century Ireland and to ask whether they could have been sustained in the face of continued population pressure. Since the key constraint on vegetative plant growth during this period was nitrogen, a model of nitrogen availability is constructed and calibrated using historical and present day evidence, including some from reconstructions of nineteenth-century agricultural practice. The contributions of various labor-intensive practices are assessed, as are certain peculiarities of Irish climate and vegetation. The model is simulated to assess whether this system of agriculture had reached its limits before the famine.

VALERIE HALL, SCOTT LAIDLAW, Queen 's University of Belfast, AND PETER SOLAR, Queen's University of Belfast and Vrije Universiteit Brussel

\section{Cultivation and Cropping Patterns and Trends: Kaira District, circa 1820-1858}

This paper identifies the cultivation practices and cropping patterns in Gujarat's Kaira district during the second quarter of the nineteenth century, explains the cultivation and crop choices made by her agriculturists, and estimates the per capita food available to her population after meeting the state's revenue demand. During the early $1820 \mathrm{~s}$ land use and cultivation techniques were relatively intensive, and agricultural production was overwhelmingly concentrated on food and fodder crops. Three decades later, despite the expansion of high-value, nonsubsistence crops, 90 percent of cultivated land remained under grains, millets, and pulses. Cultivators' crop choices evidenced responsiveness to changes in the relative prices of inputs and outputs and were consistent with rational, risk-averse behavior by individuals with long time horizons. Intensified land use, and labor-intensive crop choices and cultivation practices were adaptive responses to increasing population densities. Per capita net food availability declined between 1820 and 1858 despite the ability of cultivators to sell a smaller proportion of their subsistence crops to meet the state's land revenue demand.

MARCIA J. Frost, Denison University

\section{Deflation and the Taiping Rebellion in China}

Not satisfied with the Malthusian and Marxist interpretation of the nineteenth-century social upheaval in China known as the Taiping Rebellion, the author proposes that the uprising can be to a greater extent attributable to monetary deflation in consequence of silver drain at the time. Deflation brought hardship to virtually all sectors of the economy, but the peasants were hit the severest. First, the terms of trade between farm products and non-farm products worked against them; their purchasing power declined. Next, they found their secondary income from handicrafts and off-farm work shrinking. Third, their burden of the land tax was increasing instead as most of it was fixed in silver. In these circum- 
stances, their fared the worst in the highly commercialized area such as the Yangzi delta, for their income was most sensitive to market fluctuations.

Yeh-CHIEN WANG, Academia Sinica, Taipei

\section{SESSION 2A: CONTRACTS AND CONTACTS: TRANSACTING IN EARLY MODERN EUROPE}

A Mechanism of Venice: The Design of Maritime Agency Relations in Venice, 1190-1220

The financing of maritime trade in the later Middle Ages presents the economist with some puzzles_-puzzles which have not been uniformly addressed or sometimes even recognized in earlier literatures on Italian commercial practices. The puzzles (and the solutions to them) turn out to have features that emerge in a broad range of contracting problems as well as in very abstract theoretical work on contract design. In twelfth and thirteenth century Venice, the financing of overseas trading ventures entailed advances of funding from investors to trading agents who would travel abroad to foreign ports. In 11901220 we observe an increasing volume of contracts in which gains and losses were distributed as functions of agents' reports. The puzzle is that investors could neither observe nor verify agents' reports-Why would agents not systematically cheat? The paper identifies a class of nonreputational mechanisms that preclude cheating, and my data indicate that Venetian merchants did in fact employ such mechanisms.

DEAN WILliamson, California Institute of Technology

\section{A Tale of "Benevolent" Governments: The Regulation of Credit Markets in Tuscany, Umbria, and Venice, Ca. 1284-1450}

By relying on the 1427 Florentine Catasto, the paper sheds new light on the age, household structure, land holding, profession and wealth of the Jewish moneylenders' clientele in Pisa and Arezzo- two large towns belonging to the Florentine domains. It then compares these findings with those I previously found for five smaller Tuscan towns. The question is whether the greater competition by Christian lenders that Jews faced in the two larger towns changed the terms at which they were allowed to set in the towns and lend money there. In particular, were the local governments of the larger towns still willing to lock themselves in with Jewish moneylenders in long term contracts, and to allow them to charge a comparatively higher interest rate ( 30 percent) than the 15 percent allowed to Christians by usury laws? Quite surprisingy, I find that more competition by Christian lenders did not lower the interest rate ceiling granted to Jewish moneylenders, and I offer an explanation for this fact.

MARISTELla BOTTICINI, Boston University

\section{The Social Foundations of Renaissance Market Structure}

The paper uses unparalleled transactional data (several thousand records gathered by the authors from the 1427 catasto) between companies in various key sectors of the Renaissance Florentine economy-banking, wool manufacture, silk manufacture, and cloth retailing - to develop a network theoretic understanding of the structure of a paradigmatic early modern market. We assess how transactional patterns in general, and the different 
patterns within different markets and industries, are linked to underlying patterns of social or economic network structure, such as patterns of interfamily marriages, interlocking partnerships, neighborhood co-residence, comparable political status of company owners, and factional allegiance. Both simple stochastic distributions of ties and more subtle benchmarks are used to assess the significance of patterns found, and a logit model is used to evaluate the importance of different background status attributes-income, political leanings, neighborhood of residence-for determining patterns of network involvement on the part of individual actors.

John F. PADGETT AND PAUL MCLEAN, University of Chicago

Recovering Pricing Mechanisms: Dealer-dealer Trade in Paintings, Antwerp to Paris, in the Seventeenth Century

Under depressed domestic conditions art dealers in seventeenth century Antwerp had to explore new products and export markets. One major market was Paris. The paper explores the long-term relationship between two dealers, one in Antwerp, the other in Paris. The Paris dealer placed orders, which were filled and shipped by his Antwerp counterpart, who played the role of principal since he owned the paintings till sale and remittance of funds from Paris. These two tried three forms of pricing arrangement in the course of their relationship. After a tentative mutual feeling-out phase, they tried alternate offer pricing, finally adopting posted prices (set by the principal) with sale-or-return clause. The sequence has logic to it: the middle arrangement was well suited to discovery of agent commitment and the importance of local market knowledge. This logic has been replicated in an experiment. The example, therefore, though historically specific, captures more general imperatives.

NeIl De Marchi, Hans VAN MIEgRoET, Duke University AND MATT RAIFF, Pennsylvania State University

\section{SESSION 2B: CONVERSING AT THE BORDERLANDS OF LAW AND ECONOMIC HISTORY}

\section{Self-Ownership and the Rights of Women}

At the time of the American Revolution, women were essentially the property of men, either their fathers' or husbands'. They could not vote, and with few exceptions, women could neither own property, enter contract or join non-religious social and professional organizations. Nearly all of the restrictions on women common in 1776 have been removed. Using a property rights model, we study the evolution of women's property rights allocated through judicial decisions, statutes, constitutional provision, and social norms. We characterize this as a shift from a regime in which men controlled women and owned their output to a regime in which women own themselves and their output and contract freely with others. In particular, the model shows how greater gains from human capital investment increase the gains from self-ownership. We empirically examine several important instances of changes in women's rights, including the granting of feme sole status under coverture, the adoption of the married women's property acts, and women's suffrage. 


\section{Antebellum Employment Law: Slaves, Animals, and Free Persons}

Antebellum Southem employers faced two labor forces-slave and free-and two sets of laws. Hiring a slave often generated the same rights and responsibilities as hiring a work animal. Accordingly, appellate courts applied some common principles to hiring disputes over slaves and over beasts. But slave cases appeared more often and required more subtle reasoning than animal cases because hired slaves substituted for free employees. Like free workers and unlike beasts, hired slaves had legal duties to behave like "reasonable persons." Despite seemingly similar behavioral standards, slaveowners collected damage awards in labor disputes far more than antebellum free employees. In fact, free workers throughout the nineteenth century rarely won lawsuits for on-the-job injuries. Why the dissimilar laws? Two reasons seem plausible: differences in the potential use of market mechanisms for risk shifting (due to moral hazard problems in the slave-hire market) and differences in the political power of capital and labor.

JenNy BouRne WaHL, St. Olaf College and Carleton College

\section{Civil Litigation and Economic Change: Evidence from New South Wales District Courts: $1860-1900$}

I employ a data set of disputes from the developing colony of nineteenth-century New South Wales to assess the relationship between legal disputes and economic change. The data are unusual in the inclusion of information on the population of disputes - both cases that are settled and those that go to court-as well as estimates of legal costs and the amount of money at issue. First, the paper considers microeconomic explanatory factors of legal proceedings, in terms of expected costs and benefits, controlling for variation across regions, level of urbanization, and classes of dispute. Second, I relate changes in settlements and litigation to macroeconomic variables such as inflation, level of industrialization, and proxies of income. The results provide insights into the economic history of civil litigation that also add to our understanding of current issues in law and economics.

B. Zorina Khan, Bowdoin College

\section{The Economic and Demographic Impact of the Alien Land Laws on Japanese Immigrants}

Opposition to immigration from Japan in the early 1900s led to Alien Land Laws which barred Japanese immigrants from buying or leasing farmland. Historians of Japanese Americans have disagreed over the effectiveness and impact of these laws. Economic historian Robert Higgs (1978) argued that these laws proved to be impotent because competitive markets pressures led to widespread evasion of the laws. Others have argued that these laws did serious damage to Japanese immigrant farming and that competition from Japanese American farmers may have contributed to discrimination.

This paper concludes that the Alien Land Laws did have a negative impact on Japanese immigrant farming and that farm groups supported the Alien Land Laws. Further, since proponents of the Alien Land Laws were interested in restricting Japanese immigration, the Alien Land Laws were also a "success" in that they did contribute to the emigration of Japanese from the United States. 


\section{SESSION 3A: THE BACKBONE OF HISTORY: HEALTH AND NUTRITION IN THE WESTERN HEMISPHERE}

\section{Measuring the Standard of Living using Skeletal Remains}

Traditional measures, such as GNP per captia or real wages are unavailable and of doubtful validity for studying very long-term trends in the quality of life. This paper develops a methodology for measuring health aspects of the standard of living from skeletal remains. Bones register conditions of chronic stress in the form of stature, degenerative joint disease, dental health, anemia, trauma and infections. These attributes are combined to create a health index that is estimated for 12,500 skeletons from various ethnic groups at 65 sites throughout the Western Hemisphere from $5000 \mathrm{BC}$ to the early twentieth century. The results show wide variations in health status, in which Native Americans were among the healthiest and least healthy. A moderate decline in health occurred in the millennia prior to the arrival of Columbus. American slaves were near the bottom of the rankings, registering indicators of chronic stress comparable to Native American populations threatened with extinction.

Richard H. STECKel, Paul W. Sciulli, Ohio State University, AND JEROME C. ROSE, University of Arkansas

\section{A Biohistory of Health and Behavior in the Georgia Bight: Interfacing Economics and Human Biology}

This study uses the remains of 1,413 individuals to address two major events that affected the lives of Native Americans along the Georgia coast: first the adoption and intensification of agriculture, especially maize, in the period 1150 to 1500 ; and second, the arrival of Europeans (Spaniards) and the establishment of Roman Catholic Missions in the period 1550 to 1702 . The precontact preagriculturalists pursued a foraging lifeway based on hunting, gathering, and fishing. The precontact agriculturalists continued using these resources, but became dependent on maize agriculture. During the contact period, native populations intensified production and consumption of maize. Moderate declines in health, in the form of dental decay and skeletal infections, accompanied the adoption of agriculture. Health deterioration intensified with European contact, as signified by increases in anemia and especially by a considerable rise in degenerative joint diseases associated with heavy manual labor.

CLARK SPENCER LARSEN, University of North Carolina ALFRED W. CROSBY, University of Texas MARK C. GRIFFIN, Moorhead State University DALE L. HutCHINSON, East Carolina University CHRISTOPHER B. RUFF, Johns Hopkins University KATHERINE F. RUSSELL, University of Massachusetts, Dartmouth MARGARET J. SCHOENINGER, University of Wisconsin LESLIE E. SERING, University of Michigan

SCOTT W. SIMPSON, Case Western Reserve University JEFFRY L. TAKACS, University of North Carolina AND MARK F. TEAFORD, Johns Hopkins University 
The Poor in The Mid-Nineteenth Century Northeast: Evidence From The Monroe County Almhouse, Rochester, New York

The excavation and study of 300 individuals from the Monroe County Poorhouse cemetery provides a valuable opportunity to compare skeletal health with that of inmates recorded in the historic documents. Almshouses were designed to relieve poverty while acting as a deterrent to public dependency. Often, deterrence was valued over relief, as many almshouses were dilapidated, overcrowded, and disease infested. Both skeletal and documentary evidence suggests that children at the almshouse had high death rates and suffered nutritional stress as indicated by enamel hypoplasia, porotic hyperostosis, and cribra orbitalia. Historic records indicate that many adults died from infectious dieases such as cholera and typhus fever. However, the skeletal indicators suggests that most of the adults buried in the cemetery suffered little biological stress as children. The combination of documentary and skeletal evidence suggests that the Monroe County Almshouse was not successful in buffering the effects of poverty.

RosANNE HigGins, State University of New York at Buffalo MiCHAEL HAINES, Colgate University

LORENA S. WALSH, Colonial Williamsburg AND JOYCE SIRIANNI, State University of New York at Buffalo

\section{SESSION 3B: CULTURE, NETWORKS, AND ORGANIZATION IN TECHNOLOGICAL CHANGE}

Steam Engines from the Elites: American Technological Change, 1790-1820

American social, political, and economic elites furnished potent support for the penetration of steam engines into urban-industrial life. Their support devolved from the early use of steam engines for urban waterworks, innovation of the steamboat, and application of steam engines for power in factories. Design and construction of steam engines required large-scale capital that only these elites could muster through personal investment or extraction of financing and other support from government. Steam engines had to be built in iron foundries or specialized engine firms because they had large investment in fixed capital of buildings, equipment, and skilled labor. Social, economic, and political elites in New York and Philadelphia worked with mechanics and engineers to found early steam engine producers. These groups forged close intra- and interurban ties that contributed to their early dominance of steam engine manufacture in the East, a precursor of the heavy industrial machinery industry.

DAVID R. MEYER, Brown University

Organizational Innovation and the Latifundium: The Purpose of the Colono Contract in Cuban Sugar, 1889-1929

This paper challenges the conventional view of the emergence of the sugar latifundia in Cuba by using the new institutional economics to provide a framework for analysis. Latifundizacion in Cuba is associated with both land acquisition and restrictive long-term contracts that sugar mills had with cane growers. Critics argued that powerful mills unilaterally imposed stricter contractual conditions on growers over time. This paper examines key clauses of growers' contracts that changed over time. It shows that early con- 
tracts were not effective in preventing opportunistic behavior by growers. Learning resulted in additional restrictions that effectively converted residual to specific rights of control and transferred them from growers to mills. Although one outcome of the transfer of rights was that growers lost control over daily operational decisions, the transfer was made because concentrating rights of control in mills' hands enhanced the coordination needed for efficient sugar production and reduced transaction costs.

ALAN DYE, Barnard College

\section{Did Imperial Policies Doom the Indian Textile Industry}

When the British left India in 1947, the economy was only slightly more industrialized than when they had taken formal control nearly one hundred years earlier. The question is, were they responsible for the lack of development? Two strains of argument suggest they were. The first, primarily associated with Amiya Bagchi, faults the British for not giving sufficient protection to domestic industries. The second, associated with Morris Morris, faults them for not investing in infrastructure-specifically the capital market and education. This paper re-examines the history of cotton textile production, the most important factory industry in colonial India. There is no evidence that any of these factors contributed significantly to the slow interwar growth of the industry. Thus, there is no basis for arguing that a national government could have speeded up development. The problems were imbedded in the structure of the labor market, beyond the control of any government.

SUSAN WOLCOTT, Temple University and American University

\section{SESSION 4A: WELL FED, WELL-OFF, AND TALL? WHAT DO WE REALLY KNOW ABOUT THE STANDARD OF LIVING IN THE PAST?}

\section{Climate, Grain Production and Nutritional Status in Southern Germany During the Eighteenth Century}

What determined nutritional status in the eighteenth century? Long time series have been created on European climatic history in recent years, making it possible to compare these data sets with new estimates of nutritional status, grain production and real wages in Southern Germany. From the late 1720 s to the late 1740 s, winter temperatures in central Europe rose by 0.6 degree Celsius, and fell in subsequent decades by about 0.8 degree Celsius. Milder winter temperatures around mid-century influenced food production positively in Southern Germany. It kept pace with the growing population during this time period, and real wages did not decline up to the 1750 s. Therefore, the development of nutritional status was positive. The cold winters after mid-century, however, had an extremely negative effect on food production, real wages, and nutritional status.

JOERG BATEN, University of Munich

\section{A Most Wretched Class: Heights, Health and Nutrition of Free Blacks in Antebellum Virginia}

Antebellum Virginia's free black population experienced a long-run decline in heights commencing with the 1780 birth cohort. Additionally, the black-white height differential increased throughout the era despite the long-noted secular decline in white heights. This 
black-white height disparity is related to two factors: a lower nutritional status among blacks than whites; and a more virulent disease environment faced by blacks. In particular, the incidence of hookworm infection among black children was about twice that suffered by whites which resulted in stunting and shorter adult stature among blacks.

HOWARD BODENHORN, Lafayette College

Anthropometric versus Conventional Economic Measures of the Standard of Living: A Search for Theoretical Consistency

Anthropometric measures, principally heights, have been proposed as a substitute for real-income measures of the standard of living. In this paper the theoretical connections between height, real income, and utility (the basis for assertions about the standard of living) are explored. If heights are driven by nutrition, then potential endogenous trade-offs such as the substitution into better-tasting but less nutritious foods, despite rising incomes in the early modern era, make heights non-monotonically related to, and thus an unreliable proxy for, utility-based measures of the standard of living. By contrast, if heights are driven by exogenous disease, toxin, and climate shocks, then heights are a utility-consistent measure of the standard of living when other exogenous shocks are absent. Thus, by more than offsetting an exogenous fall in heights, the industrial revolution had a larger positive impact on the standard of living than previously thought.

MARY ESCHELBACH GREGSON, Knox College AND FARLEY GRUBB, University of Delaware

\section{SESSION 4B: THE WEALTH OF NATIONS AND THE EXTENT OF THE MARKET}

The Economic History of the Super-Long Run: A Possible Dialogue Between Archaeology and Economic History

Recent archaeological findings indicate much higher levels of economic organization and productivity than the conventional views held by most economic historians generally admit. This record constitutes a primary source of information for students of long-run economic change. This paper reviews the evidence and proposes a search-equilibrium model to explain it.

GEORGE GRANTHAM, McGill University

\section{Re-thinking Eighteenth-Century China: a High Standard of Living and its Implications}

This paper uses cropping patterns to reconstruct eighteenth-century Chinese living standards. The results are surprising: not only higher grain consumption per capita than Europe, but per capita sugar consumption close to double that of continental Europe circa 1800, and per capita cloth consumption comparable to that of France; for the richest part of China (Jiangnan, with over $30,000,000$ people) per capita cloth output was about the same as for the U.K. Further comparisons, focusing on female textile producers, suggest that this standard of living was built on processes of household labor re-allocation and increased market involvement similar to those which Jan deVries has labelled the "industrious revolution" in Europe. This forces us to re-consider what, if anything, was unique about Europe on the eve of factory industrialization. After making further comparisons of demo- 
graphic and ecological variables, the paper suggests possibilities which emphasize the different relationships between proto-industrial and agricultural areas in the West and in East Asia.

\section{KENNETH POMERANTZ, University of California, Irvine}

\section{Glory Days? Work Hours, Labor Market Regulation and Convergence in Late Nineteenth Century Europe}

In late nineteenth century Europe there was growing concern that returns to labor were diverging across countries. Drawing on the insights of contemporary observers, we construct two new data series, one on the changing pattern of European work hours between 1870 and 1900, and the other on the rate of introduction of labor market regulation and social insurance in Europe between 1830 and 1914. We find that national labor markets were insulated from the forces of globalization.

\section{Michael Huberman, Université de Montréal AND WAYNE LEWCHUK, McMaster University}

\section{SESSION 5A BETWEEN THE WARS: GOLD, EXPECTATIONS, AND THE DISTRIBUTION OF SUFFERING}

\section{Threat of a Capital Levy, Expected Devaluation and Interest Rates in Interwar France}

In this paper we try to isolate and measure the respective importance of political and economic aspects in two critical episodes of the French interwar period: the stabilization process of the mid-1920s and the reluctance to abandon the gold standard during the 1930s. We do this by separating expectations of taxation and of devaluation that are implicitly included in the prices of various categories of French and foreign bonds. About the 1924 1926 crisis, we show first that there was no expectation of a government default; second that a substantial part of the high level of interest rate in 1925 can be explained by expectations of a capital levy or other taxation devices; third that hyperinflation was not expected even at the moment of maximum price rise since implied five years interest rate was about 25 percent and since expected exchange rate was then much below the actual one. For the 1930s, we show that expectations of a depreciation of the franc explain the rise in interest rates, so that no independent effect of taxation was expected.

\section{PIERRE-CyRILLE HAUTCOEUR, Rutgers University AND} PIERRE SICSIC, Banque de France

The Sources of Regional Variation in the Severity of the Great Depression: Evidence from U.S. Manufacturing, 1919-1937

The severity of the Great Depression in the United States varied by region. Most notably, compared with the rest of the country, the South Atlantic states experienced a milder contraction, while the Mountain states suffered more severely. The impact of the contraction was fairly similar across other regions of the country surprisingly so, considering the large regional differences in industrial structure. We employ data from the biennial Census of Manufactures on 20 individual manufacturing industries disaggregated by state to analyze the relative contributions of industry mix and location to regional variations in economic performance during the period 1919 to 1937 . Industrial composition 
had a significant impact on regional employment growth, with regions that concentrated on the production of durable goods or inputs to the construction sector tending to fare worse than others. Long-run regional trends also played an important role in regional variation, and explain much of the South Atlantic region's more favorable performance over the cycle.

JOSHUA L. ROSENBLOOM University of Kansas and NBER, AND WILlIAM A. SUNDSTROM, Santa Clara University

\section{The Gold Standard, Uncertainty, and Delayed Recovery in Interwar France}

The path to economic recovery from the Great Depression was cleared for many countries by severing the link between their currencies and gold. One exception was France, whose economy grew slowly after it left the gold standard in 1936. Explanations for this halting recovery that have appeared in the literature include fears of a return to the inflationary conditions of the mid-1920s and a supply shock that resulted from labor policies. We suggest another channel in this paper-that political uncertainty associated with devaluation helped retard economic recovery. To test this proposition, we first estimate conditional interest rate variances as a proxy for uncertainty. Next, we incorporate this measure into standard econometric models that explain real activity, while controlling for other explanatory variables. Our preliminary findings show that uncertainty played a critical role in inhibiting France's recovery from the Great Depression.

\section{J. PETER FERDERER Macalester College AND} David A. ZalewsKi, Providence College

\section{SESSION 5B: MIND OVER MATTER: THE RHETORIC OF MARKETS}

\section{Profitable Imaginings: Utopia and Project in Seventeenth-Century England}

This paper is part of a project investigating English reactions to and imaginings of early modern economic and industrial developments. I am particularly concerned with how attitudes toward innovation, toward acquisition, toward production, and towards profit impact upon and are impacted by various literary genres in the early modern period. Through examining the various texts (called project tracts) which promote technological and economic enterprise in the period, and through looking at other groups of writings which comment on and react to the projects, I hope to shed light on the rhetoric and circumstances of two seventeenth-century utopias. Francis Bacon's The New Atlantis and Gabriel Plattes's Macaria engage with many of the project tract concerns. In focusing on the relationship of these two genres, I will examine how the acquisition and investment of wealth is increasingly overtly articulated as a necessary requisite for the health and prosperity of the seventeenth-century English nation.

Samantha Heller, Columbia University

The Meaning of the Market: Agricultural Reform and Political Values in the French Revolution

This paper offers a new interpretation of the relationship between politics and economics in the French Revolution. It argues that the exogenous conditions for a market based econ- 
omy were generated in the Revolution. The premises of public moral argument in favor of such an economic rationality were articulated by political elites in the period. The republican tradition, in particular, was reconciled to economic modernity and promoted a renovated political economy. Moreover, distinctive features of French economic organization, such as the alliance of state and private interests, were also generated at this time. This institutionalization of new economic attitudes was best seen in the efforts at agricultural reform conducted from 1795 to 1799 . Some comparisons with contemporaneous developments in Britain help to reinforce the modernizing tendencies of the revolutionaries. The revolution, therefore, promoted the cultural and structural conditions for a market-based economy.

JAMES LIVESEY, Trinity College, Dublin

\section{Moral Persuasion: Arguments for Political Economy in the July Monarchy}

The French Academy of Moral and Political Sciences, created in 1832, had the task of producing, evaluating, and disseminating information in the social sciences, including political economy. To convince the elites to accept their free trade political economy as science and to adopt its teachings, the Academicians used several rhetorical arguments. This paper concentrates on the Academy's polarized definitions of destitution and happiness to link the economic and the moral spheres. In this way, the Academicians created a powerful rhetoric of good and evil that was used to recode moral and immoral behavior, to promote as scientific free trade economics and discredit others, such as protectionism and socialism, and to define appropriate government action. Examined in this light, the Academy's work demonstrates a sustained effort to apply rhetoric as a means to persuade a much divided elite class on how to create and sustain a stable and prosperous, postrevolutionary society.

MARY E. CHALMERS, University of Central Arkansas

\section{SESSION 6A: CLEANING UP: EXPLORING THE DOMESTIC ECONOMY}

\section{The Emergence of Domestic Service as Wage Labour for London Women}

In the late seventeenth and early eighteenth centuries in London, the institution of domestic service, organized according to long-held patriarchal social principles but changing under new social and economic stressors, provided an important context for the emergent economic phenomenon of female wage labour. The increasing divergence of the traditional institution of service from the recorded experiences of London domestics was grounded in new and disjunctive social and economic conditions in the capital. These conditions were domestics' high degree of mobility and contemporary efforts to regulate it, new legislation concerning servants' pay, and polemical and prescriptive writing that demonstrated intense anxiety around the issue of wage rates for female servants in particular. The evolution of the "yearly wage" generated a new understanding of service as a contract relationship a relationship only reluctantly undertaken by employers of female servants, because it eroded paternalistic norms and therefore power. 
The Acquisition of Domestic Skills in Britain, Ireland, and North America in the Late Nineteenth and Early Twentieth Centuries: The Role of Adaptive versus Cultural Learning

This paper examines how domestic skills have been acquired in Britain, Ireland and North America since the mid-nineteenth century. One view of the process of domestic skill acquisition emphasizes the importance of mother to daughter transmission, or what could be described in more general terms as cultural learning through tradition. This paper argues in contrast that alternatives to mother to daughter transmission have played an important role in the transmission of domestic skills. These alternative mechanisms feature what has been termed adaptive learning or in other words direct response to one's immediate environment. This conclusion is based on surveying historical accounts of domestic tasks and of how skill and knowledge of those tasks have commonly been acquired. The importance of adaptive learning in acquiring domestic tasks can be attributed to the fact that daughters have commonly faced fundamentally different situations in running a household than their mothers. Evidence from a variety of literatures is used to gauge the likely quantitative impact of changes in the effectiveness with which domestic skills have been acquired.

DAVID MITCH, University of Maryland, Baltimore County

\section{Housework, Health, and Knowledge: Why Was There More Work for Mother?}

This paper proposes to reexamine the issue of changes in housework in the period after 1880 as a consequence of the changed perceptions of people regarding the impact of cleanliness and similar products of domestic labor on health and longevity. The paper will examine in which ways the new microbial theory of disease influenced homemakers to allocate more time to housework as they re-evaluated the responsibilities of women regarding the physical well-being of household members. The paper will assess the effect of these changes on the roles of married women in the family and in the economy at large.

JOEL MOKYR, Northwestern University

\section{SESSION 6B: VISIBLE HANDS? FINANCE AND ORGANIZATION}

\section{Law, Competition, and Organizational Innovation in German Steel, 1871-1936}

Recent literature on American business history (Neil Fligstein, Tony Freyer, Mark Roe) has drawn attention to the important effect of antitust legislation on the shape of American business organization. All these interpretations have "put politics back into" the trajectory of American business and offer an alternative to the Chandlerian model. This paper contrasts the American corporate experience with the German corporate experience in a "land of cartels" and universal banks. The study examines the German rationale for allowing cartels and then their impact on the competitive dynamics of the steel industry and individual business organizations. By the 1920 s, the dynamics of market competition under the cartel system and strategic organizational choices ironically undermined the very basis of German corporate law itself, forcing the lawyers, businessmen, bankers, and politicians to find an ingenious legal solution to the question: what is a firm? The paper presents a more dynamic interactive explanation which goes beyond the debate about the primacy of politics or markets. 


\section{The Rise of Multiunit Firms in U.S. Manufacturing}

This paper documents the growth of the modern multiunit firm in U.S. manufacturing during the twentieth century and examines the forces which led to its rise and continued growth. The multiunit manufacturing firm emerged in the United States during the last two decades of the nineteenth century and displaced the traditional single-unit firm in a number of industries. However, because census type information on firms does not exist for that period, historians have relied on a relatively small sample of firm histories of the very big enterprises to examine the emergence of multiunit firms. This paper utilizes the census bureau's enterprise statistics which provide complete firm level information for the period between 1954 and 1987 to examine the rise and spread of multiunit activity in U.S. manufacturing. The paper finds that multiunit firms emerged and grew in a cluster of industries which were characterized by economies of scale, scope, research and development, sales administration, and intensities in capital and energy.

SUKKOO KIM, Washington University and NBER

\section{Wall Street to Main Street: Charles Merrill and Middle Class Investors}

This paper focuses on the major contribution of financial entrepreneur Charles Merrill to the development of the U.S. capital markets in the middle decades of the twentieth century. The founder of Merrill Lynch \& Co., this entrepreneur had three successful business careers: as merchant banker and investor in the 1920s; as controlling owner of Safeway Stores, the nationwide grocery chain in the 1930s; and as directing partner of the nation's largest brokerage chain from 1940 to 1956. Because of the Great Depression, trading volume on the NYSE plummeted in the 1930s. Brokerage was a dying business. Merrill reinvigorated this sector by introducing a series of innovative strategies and policies aimed at the solicitation of upper middle class households residing beyond the major metropolitan areas. He hoped to compete more successfully with life insurance companies by diverting a significant portion of household savings into common stocks, which promised higher returns over the long term. The firm is presently the U.S. market leader in brokerage and investment banking. The archival resources at Merrill Lynch headquarters provide the research base for the paper.

EDWIN J. PERKINS, University of Southern California 